Journal of Community Based Environmental Engineering and Management, 2021, Vol. 5, No. 2: 73-82

\title{
PLANNING OF DOMESTIC WASTEWATER FACILITIES (CASE STUDY: BABAKAN VILLAGE, CIPARAY DISTRICT, BANDUNG REGENCY)
}

\author{
Deni Rusmaya*, Evi Afiatun, Muhammad Al Hadad \\ Department of Environmental Engineering, Universitas Pasundan, Indonesia
}

\begin{abstract}
Babakan Village has a problem that there is still a lack of facilities for wastewater. This condition can be seen from the access to the toilets of 2436 households; only around 1506 families have access to family/ shared latrines and 625 households that meet technical requirements. For this reason, this plan is useful for increasing access and meeting community needs for domestic wastewater treatment facilities in the study area. This planning stage begins with a survey and sanitation inspection to determine 3 priority areas for handling. Determinants of this priority area use the method of scoring and weighting the risk. The weighting results put sub village 02 with a score of 2.3 , sub village 05 with a score of 2.25 , and RW 10 with a risk value of 2 as the priority area for planning handlers. Primary data collected will be used as a consideration for determining the technology to be applied. The technology chosen for processing is the communal septic tank for people who do not have treatment. In contrast, for the washing bath, toilet with a biofilter unit for people who do not have wastewater infrastructure.
\end{abstract}

Keywords: Wastewater Access, Communal WWTP, Weighted Risk, Scoring, Priority Areas

\section{Introduction}

Babakan Village, located at Bandung Regency, Indonesia, facing several problems concerning environmental issues (Yustiani et al., 2019). One of the problems in Babakan Village is that there are still many people who do not have a septic tank or proper disposal of household waste (Buku Putih Sanitasi, 2016). The household waste is discharged into the river or the simple septic tank, which does not follow technical requirements. The management of domestic wastewater in Babakan Village is currently not a concern of the community or government.

Domestic wastewater treatment is one of the housing health requirements in the Minister of

\footnotetext{
${ }^{*)}$ E-mail: denirusmaya@gmail.com
}

Received: 20 March 2021

Revised: 19 August 2021

Accepted: 16 September 2021

DOI: $10.23969 /$ jcbeem.v5i2.3895
Health Decree No. 892 of 1999. One of the aspects is that wastewater originating from the house is not allowed to pollute water sources, does not cause odor, and does not pollute the soil surface. Therefore, we need a way to treat wastewater so that it does not negatively impact the environment and health (Mulyatna et al., 2021)

Based on these sanitation problems, it is necessary to have a domestic wastewater management system. In this study, a community-based sanitation facility and infrastructure development for the people of Babakan Village, Ciparay District, Bandung Regency will be planned.

This study aims to plan a management system for wastewater facilities and infrastructure in the Babakan Village area. 


\section{Research Methodology}

\section{Overview of the Study Area}

Babakan Village is divided into 5 Hamlets, 18 RW (sub village) and 51 RT (Sub-sub village/ SVV). The number of residents living is 8311 people, 2401 families with 4292 male and 4019 female (Anonymous, 2018).

The location of the map of the Babakan village area can be seen in the image below:

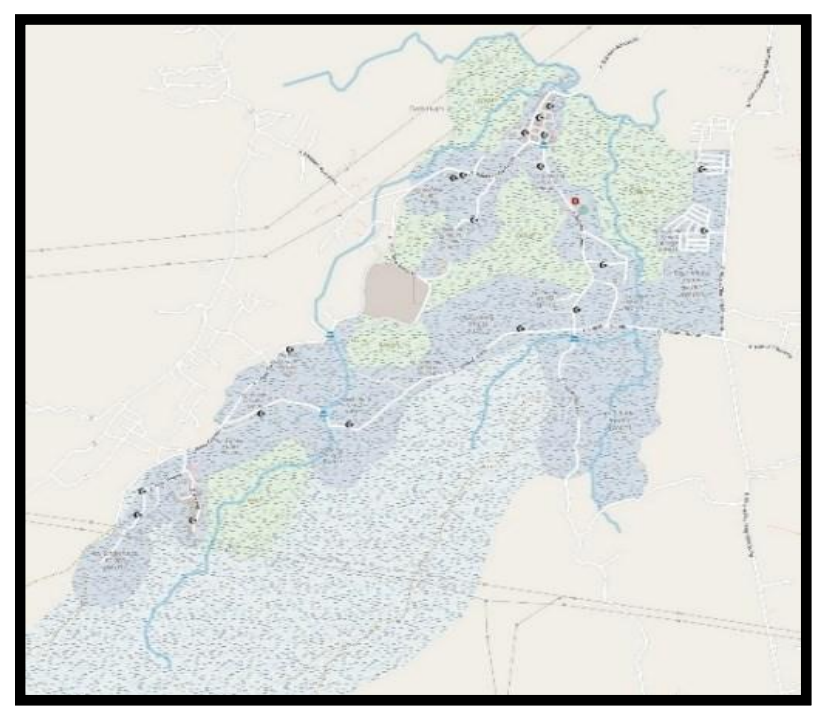

Figure 1. Map of the Planning Area

Babakan Village is located at 750 meters above sea level with a rainfall of $70 \mathrm{~mm} /$ year. The land (topography) of the plateau is 70 , the slope is $45 \%$, with an average air temperature of $28 \mathrm{oC}$ to $32 \mathrm{oC}$. The area of Babakan Village is 4883.2 $\mathrm{Ha}$, consisting of $4702.2 \mathrm{Ha}$ of residential space and $181 \mathrm{Ha}$ of Paddy fields.

Based on data from the Babakan Village office in 2019, the existing conditions of the wastewater facilities are as follows:

- The number of people having access to family toilets or shared latrines (5 families/latrines) (household units) is as many as 1506 households.

- According to technical requirements, the number of family toilets / shared latrines (having a gooseneck toilet connected to a septic tank) / (household unit) is 620 households.

- Separate household sewerage with $1 \%$ environmental drainage channel

\section{Data collection}

The data required is divided into two, namely primary data and secondary data.

a. Primary data :

The location survey is needed to directly see the conditions in the field in the form of plans for wastewater treatment facility placement and land availability.

The survey method used is an inspection to analyze the risk of wastewater facilities and infrastructure in the study area and to determine the level of community demand for clean water, wastewater, and waste facilities and infrastructure in determining priorities in providing and building sanitation facilities and infrastructure. Those are fundamental to improving standards of living for people (Bartram \& Cairncross, 2010).

b. Secondary Data:

- Village Profile Data

- Population Data

- $\quad$ Sanitation facility data

\section{Determination of Number of Respondents}

Determination of the number of respondents is using the Slovin formula. This is based on the known population size (Ariola, 2006).

The house equation used is:

$n=\frac{N}{1+N e^{2}}$

Therefore:

$n=\frac{2404}{1+2404 \times(0.1)^{2}}$

So, the number of respondents was spread to as many as 96 families. The selection of respondents was carried out by non-random 
proportional sampling based on the number of samples of households in each RW.

The following formula is used in sampling as follows:

$f i=\frac{N i}{N}$

$n i=f i \times n$

The following is a table of the number of samples for each sub-village (RW).

Table 1. Number of samples

\begin{tabular}{|c|c|c|c|}
\hline No & $\begin{array}{c}\text { Number of } \\
\text { RW }\end{array}$ & $\begin{array}{l}\text { Number of } \\
\text { Population }\end{array}$ & $\begin{array}{c}\text { Number } \\
\text { of } \\
\text { samples }\end{array}$ \\
\hline 1 & RW 01 & 169 & 7 \\
\hline 2 & RW 02 & 214 & 7 \\
\hline 3 & RW 03 & 174 & 7 \\
\hline 4 & RW 04 & 157 & 6 \\
\hline 5 & RW 05 & 150 & 7 \\
\hline 6 & RW 06 & 90 & 4 \\
\hline 7 & RW 07 & 152 & 6 \\
\hline 8 & RW 08 & 95 & 4 \\
\hline 9 & RW 09 & 109 & 4 \\
\hline 10 & RW 10 & 89 & 4 \\
\hline 11 & RW 11 & 120 & 5 \\
\hline 12 & RW 12 & 178 & 7 \\
\hline 13 & RW 13 & 154 & 6 \\
\hline 14 & RW 14 & 175 & 7 \\
\hline 15 & RW 15 & 140 & 6 \\
\hline 16 & RW 16 & 46 & 2 \\
\hline 17 & RW 17 & 105 & 4 \\
\hline 18 & RW 18 & 79 & 3 \\
\hline \multicolumn{2}{|r|}{ Total } & 2404 & 96 \\
\hline
\end{tabular}

\section{Distributing Questionnaires}

The first phase of the questionnaire was distributed in all areas of the Babenna Village in 18 RWs. Filling out the questionnaire was carried out by direct interview and inspection of wastewater facilities and infrastructure by observing the respondents' facilities and infrastructure conditions.

Sanitation inspection examines the condition of facilities and infrastructure to obtain information on potential risks of wastewater facilities.

\section{Determination of Risk Value}

The determination of the sanitation risk value in the study area used scoring and weighting methods.

a) Scoring method: a score for each question sheet to assess the condition of the wastewater facilities (sanitation inspection).

The formula used:

score $=\frac{\text { YES answers }}{\text { Total of questions }} \times 100 \%$

\section{Risk Category}

$<33 \%$ : Low $(\mathrm{R})$

$34 \%$ - 66\%: Moderate (M)

$>67 \%$ : High $(\mathrm{T})$

b) Weighting risk

Risk weighting is a decision-making technique that gives weight to these risk factors (Muhammad 2014). Weighting the risk helps determine areas that have high, medium, and low sanitation risks.

The formula used is:

Value Risk $=$ score $\times$ weight value

Weight value category (\%) (Asusmsi)

50\%: High (T)

35\%: Moderate (M)

15\%: Low (R)*Nilai asumsi yang digunkan berdasarkan analisa resiko skoring.

c) Range Value Determination

The method was used to define ranges with a distribution rule (Strurgess Rule).

d) Mapping of Sanitation risk

This mapping aims to map the risk area based on the level of risk value for wastewater sanitation. The results of the risk mapping will then be selected 3 RWs that have the highest risk value which will be designated as the study area. 


\section{Result and Discussion}

\section{Data Analysis (Phase I)}

Based on the results of questionnaires that have been distributed, it can be seen that the respondents' age group, level of education, occupation, and income.

In the age group most of the respondents were dominated by the age group $<48-56$ as much as $26 \%$ and the age $<39-45$ as much as $25 \%$, in the education level group most of the respondents were graduated from elementary school, namely $73 \%$, in the type of work most of the respondents were laborers / coolies, namely $52 \%$, for the majority of income is still below 1 million, which is $46 \%$ and for the number of children per family is less than 5 people by $39 \%$. The percentage can clearly be seen in Figure 3 .

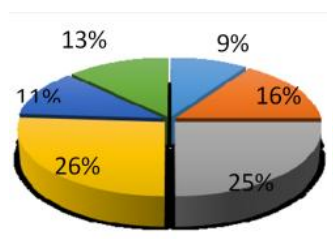

A

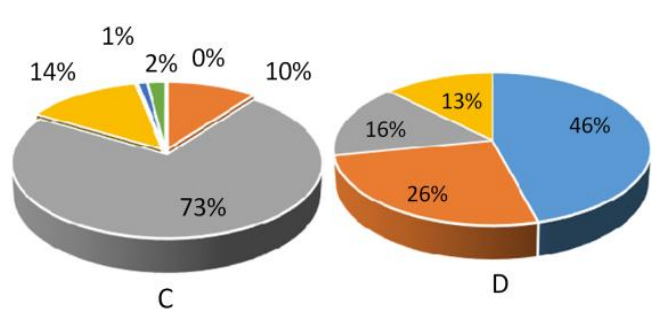

Figure 3. A. Age, B. Employment, C.

Education, D. Income

\section{Wastewater Access}

Access to wastewater facilities in the study area consists of several components in the questionnaire. Some of the aspects that are of concern in the questionnaire include: The place where family members defecate (ODF), the place where waste water is channeled, and the impact of direct disposal of waste into the environment (Hardjosuprapto, 2000), (PerMen PUPR, 2017).

The percentage can clearly be seen in Figure 4. From $100 \%$ of respondents who have private latrines, $61 \%$ of respondents. For the sanitation facilities above, it shows that $5 \%$ of respondents use shared latrines and $9 \%$ of respondents use washing baths without defecating and meanwhile $25 \%$ of respondents practice defecating in pools and empty land because they do not have private latrines at home. respondents who do not have private latrines use the shared latrine facility or share a ride with relatives.

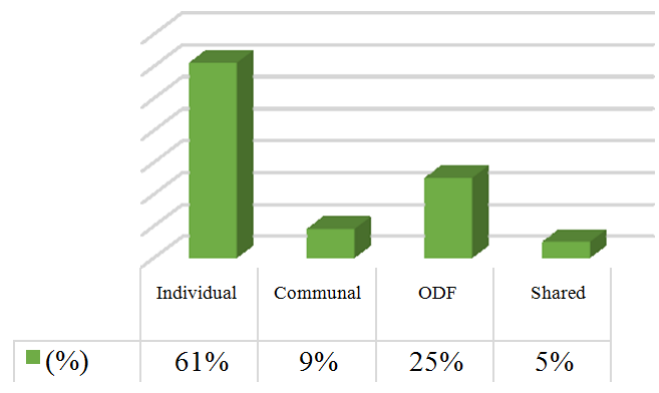

Figure 4. Wastewater Access

Note:

Public MCK: Only used for bathing and washing without defecating because there is no water closed facility (WC). ODF: Head of family / community whose access to the toilet is still defecating in ponds / ponds and rivers.

For those who have private latrines as many as $61 \%$ of respondents and $30 \%$ of respondents have private septic tanks, however, respondents who claim to have a septic tank stated that they have never drained them. From this answer, it can be ascertained that the septic tank may not be in accordance with the correct construction requirements. This was confirmed by the statement of one of the residents from Babakan village who stated that the septic tank in the area was deliberately not made tight. Meanwhile, $31 \%$ of other respondents use cubluk to distribute non-impermeable domestic 
wastewater, polluting the environment. Cubluk will be permanently closed with soil when it is full and will replace it by digging new cubluk holes as new waste water reservoirs, replacing cubluk is usually every 15 years.

From the results obtained, it can be concluded that domestic waste in the area has not been properly treated, either gray water or black water.

\section{$\underline{\text { Need for Wastewater Facilities }}$}

The need for sanitation facilities and infrastructure is needed to determine the community's response to the required sanitation facilities and infrastructure (Prameswari \& Purnomo, 2014). The questionnaire results from $100 \%$ of respondents in the study area showed that $50 \%$ of respondents needed wastewater facilities and infrastructure.

\section{$\underline{\text { Wastewater Risk Value Determination }}$}

The following are the results of the sanitation inspection scoring which can be seen in Table 2 below:

Table 2. Potential risk scoring

\begin{tabular}{ccccc}
\hline \multirow{2}{*}{$\mathbf{R W}$} & \multirow{2}{*}{$\begin{array}{c}\text { Latrine } \\
\text { ownership }\end{array}$} & $\begin{array}{c}\text { High } \\
\mathbf{( 6 - 7 )}\end{array}$ & $\begin{array}{c}\text { Moderate } \\
\mathbf{( 3 - 5 )}\end{array}$ & $\begin{array}{c}\text { Low } \\
\mathbf{( 0 - 2 )}\end{array}$ \\
\hline 01 & 4 & 0 & 4 & 0 \\
\hline 02 & 5 & 4 & 1 & 0 \\
\hline 03 & 5 & 0 & 2 & 3 \\
\hline 04 & 6 & 0 & 2 & 4 \\
\hline 05 & 2 & 4 & 1 & 0 \\
\hline 06 & 4 & 0 & 1 & 3 \\
\hline 07 & 4 & 0 & 4 & 0 \\
\hline 08 & 2 & 0 & 2 & 2 \\
\hline 09 & 2 & 0 & 2 & 2 \\
\hline 10 & 1 & 4 & 0 & 0 \\
\hline 11 & 2 & 0 & 2 & 0 \\
\hline 12 & 3 & 1 & 3 & 0 \\
\hline 13 & 3 & 0 & 4 & 0 \\
\hline 14 & 7 & 0 & 2 & 5 \\
\hline 15 & 6 & 0 & 0 & 6 \\
\hline 16 & 2 & 0 & 0 & 2 \\
\hline 17 & 1 & 1 & 0 & 0 \\
\hline 18 & 1 & 1 & 0 & 0 \\
\hline Total & 72 & 12 & 32 & 27 \\
\hline Percentage \% & $100 \%$ & $17 \%$ & $46 \%$ & $36 \%$ \\
\hline & & & &
\end{tabular}

The result of the wastewater risk assessment shows that $100 \%$ of the respondents have their own latrine. Seventeen percent $(17 \%)$ of respondents have high potential risk, $46 \%$ middle risk, and $36 \%$. In this condition, the risk value is high because the sewerage is discharged directly into the river and the latrine does not have a wall to cover the user and the latrine is not built according to the technique. Moderate condition because the toilets have less than $7 \mathrm{~m}$ of pollutant sources and the latrines are not made according to a technicality. In low state, the latrine is protected by a wall.

\section{Weighting risk}

The following are the stages of risk weighting.

Table 3. Range of Risks

\begin{tabular}{cc}
\hline Risk & Score \\
\hline Low & $<1.1$ \\
\hline Moderate & $1.1-1.7$ \\
\hline High & $>1.7$ \\
\hline
\end{tabular}

The following are the results of the risk assessment of wastewater facilities.

Table 4. Wastewater Risk Assessment

\begin{tabular}{|c|c|c|c|c|c|}
\hline \multirow[b]{2}{*}{ RW } & \multicolumn{3}{|c|}{ Risk } & \multirow[b]{2}{*}{$\begin{array}{c}\text { Risk } \\
\text { Value }\end{array}$} & \multirow[b]{2}{*}{$\begin{array}{c}\text { Risk } \\
\text { Level } \\
\end{array}$} \\
\hline & $\begin{array}{c}\mathbf{H} \\
(\mathbf{5 0 \%})\end{array}$ & $\begin{array}{c}\mathbf{M} \\
(35 \%)\end{array}$ & $\begin{array}{c}\mathbf{L} \\
(25 \%)\end{array}$ & & \\
\hline 01 & 0 & 1.75 & 0.5 & 1.7 & M \\
\hline 02 & 2 & 0.35 & 0 & 2.3 & $\mathrm{H}$ \\
\hline 03 & 0 & 0.7 & 0.75 & 1.45 & M \\
\hline 04 & 0 & 0.7 & 1 & 1.7 & $M$ \\
\hline 05 & 0.5 & 1.75 & 0 & 2.25 & $\mathrm{H}$ \\
\hline 06 & 0 & 0.35 & 0.75 & 1.1 & M \\
\hline 07 & 0 & 1.4 & 0 & 1.4 & M \\
\hline 08 & 0 & 0.7 & 0.5 & 1.2 & M \\
\hline 09 & 0 & 0.7 & 0.5 & 1.2 & M \\
\hline 10 & 2 & 0 & 0 & 2 & $\mathrm{H}$ \\
\hline 11 & 0 & 0.7 & 0 & 0.7 & $\mathrm{~L}$ \\
\hline
\end{tabular}




\begin{tabular}{|c|c|c|c|c|c|}
\hline \multirow[b]{2}{*}{ RW } & \multicolumn{3}{|c|}{ Risk } & \multirow[b]{2}{*}{$\begin{array}{c}\text { Risk } \\
\text { Value }\end{array}$} & \multirow[b]{2}{*}{$\begin{array}{l}\text { Risk } \\
\text { Level }\end{array}$} \\
\hline & $\begin{array}{c}\mathbf{H} \\
(50 \%)\end{array}$ & $\begin{array}{c}\mathbf{M} \\
(35 \%)\end{array}$ & $\begin{array}{c}\mathbf{L} \\
(25 \%)\end{array}$ & & \\
\hline 12 & 0.5 & 1.05 & 0 & 1.55 & M \\
\hline 13 & 0 & 1.4 & 0 & 1.4 & $\mathrm{M}$ \\
\hline 14 & 0 & 0.7 & 1.25 & 1.95 & $\mathrm{M}$ \\
\hline 15 & 0 & 0 & 1.5 & 1.5 & $\mathrm{M}$ \\
\hline 16 & 0 & 0 & 0.5 & 0.5 & $\mathrm{~L}$ \\
\hline 17 & 0.5 & 0 & 0 & 0.5 & $\mathrm{~L}$ \\
\hline 18 & 0.5 & 0 & 0 & 0.5 & $\mathrm{~L}$ \\
\hline
\end{tabular}

\section{Priority Location Selection}

The location of the sanitation plan with the highest risk was in the RW 02 area with a score of 10.15 , RW 05 with a score of 9.85 and RW 10 with a score of 8 .

\section{Data Analysis (Phase II)}

Determination of the number of respondents still using the Slovin formula with the number of questionnaires distributed as many as 82 samples of families with the tolerance limit used is $10 \%$, with the following details:

Table 5. Number of Respondents

\begin{tabular}{cccc}
\hline RW & RT & $\begin{array}{c}\text { Number of } \\
\text { households }\end{array}$ & $\begin{array}{c}\text { Number of } \\
\text { samples }\end{array}$ \\
\hline & 1 & & 13 \\
\hline 2 & 2 & 214 & 13 \\
\hline & 3 & & 13 \\
\hline & 1 & & 10 \\
\hline 5 & 2 & 150 & 9 \\
\hline & 3 & & 9 \\
\hline & 1 & & 5 \\
\hline 10 & 2 & 89 & 5 \\
\hline Total & 3 & & 5 \\
\hline
\end{tabular}

\section{Characteristics of Respondents}

Based on the questionnaire results, $59 \%$ of the respondents were male, and $41 \%$ were female.

In the age group, most of the respondents were $<46-54$, which was $27 \%$, in the education level group, most of the respondents were primary school graduates, namely $68 \%$, in the type of work most of the respondents were laborers / coolies, namely $52 \%$, for part income amount is still below 1 million, namely 50\% and for the most significant number of children per family is less than five people by $49 \%$. The percentage can be seen in Figure 5.

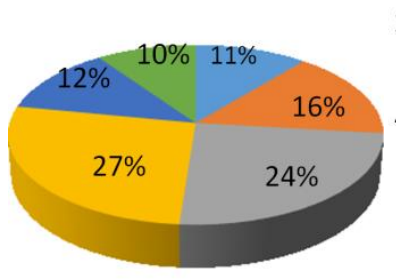

$\mathrm{E}$

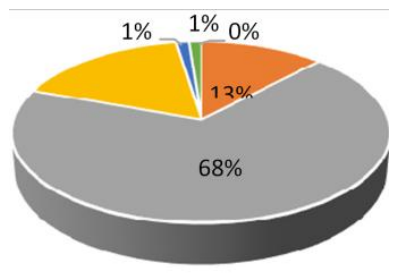

G

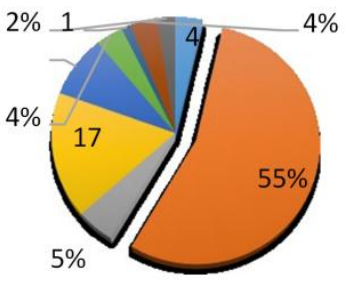

F

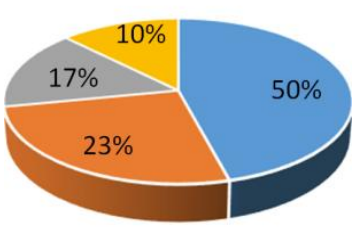

$\mathrm{H}$
Figure 5. E. Age, F. Employment, G. Education, H. Income

\section{Wastewater Access in Priority Areas}

The questionnaire results related to sanitation conditions found that $51 \%$ of respondents said they knew sanitation.

However, it is estimated that community sanitation knowledge is still limited to environmental hygiene, while other aspects of sanitation, namely domestic waste management, are still foreign to the community. From the questionnaire, it was found that $60 \%$ of respondents stated that they knew the impact of direct disposal of domestic waste to the environment. The percentage can be seen in Figure 6. 
Access to sanitation facilities shows that $60 \%$ have private latrines, $35 \%$ do not have private latrines, $4 \%$ public toilets, and $1 \%$ public toilets. The areas that do not have access to private latrines are RW 02 RT 03 and RW 10. The main reason for the difficulty of providing wastewater facilities is this economic factor as evidenced by the low income of the household head.

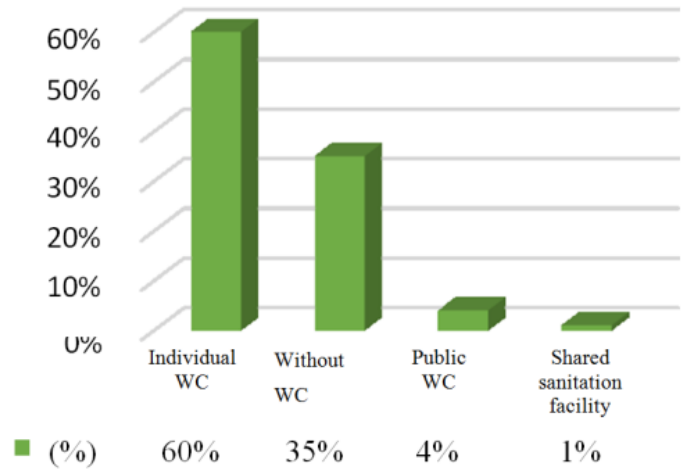

Figure 6. Ownership of wastewater facility

For private toilets, as much as $60 \%$ of them distribute domestic wastewater using nonwaterproof cubluk. Cubluk will be permanently closed with soil when it is full and will replace it by digging new cubluk holes as new waste water reservoirs; replacing cubluk is usually every 15 years. From $100 \%$ of respondents, all of them distribute used washing water to the ditch.

\section{Need for Wastewater Facilities}

The need for facilities and infrastructure from the questionnaire results from $100 \%$ of respondents in the study area is known that $57 \%$ of respondents need wastewater facilities and infrastructure.

Determination of the Location of Domestic Wastewater Facilities

\section{Mapping of the Plan of Wastewater Treatment Plant location}

Location planning for wastewater treatment system services based on the results of a sanitation risk assessment. The location of the domestic wastewater treatment plant chosen is the result of a field survey taking into account the availability of land (Setiawati, 2017).

a. Selected RW planning location

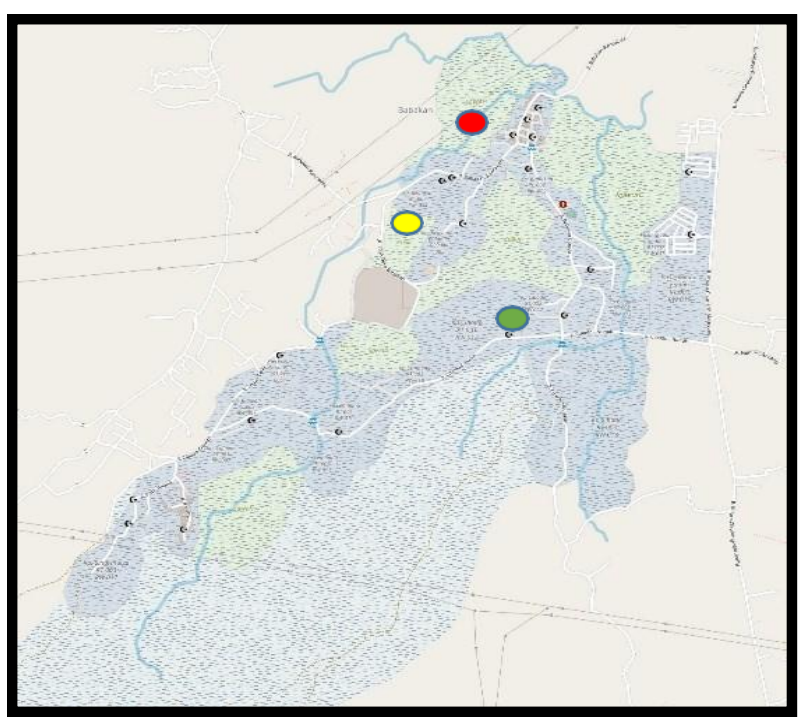

Figure 7. Map of the planning location

\section{b. Area of RW 02}

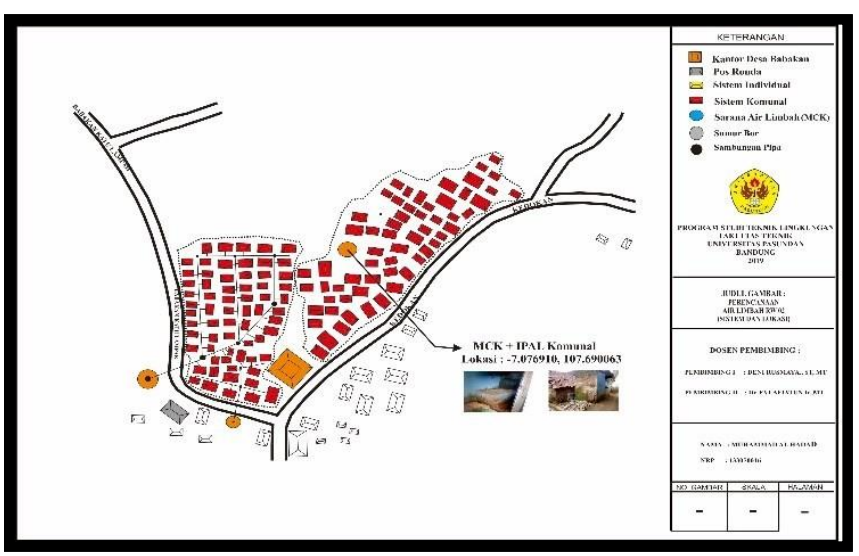

Figure 8. Location planning RW 02

Note : WWTP location

Number of HH: 214 (1 KK 5 people), SSV or sub-sub village (SSV) SSV01: 91KK (with problems), SSV 02: 81KK (no problem), SSV03: 42KK (with problems). 


\section{c. Area of RW 05}

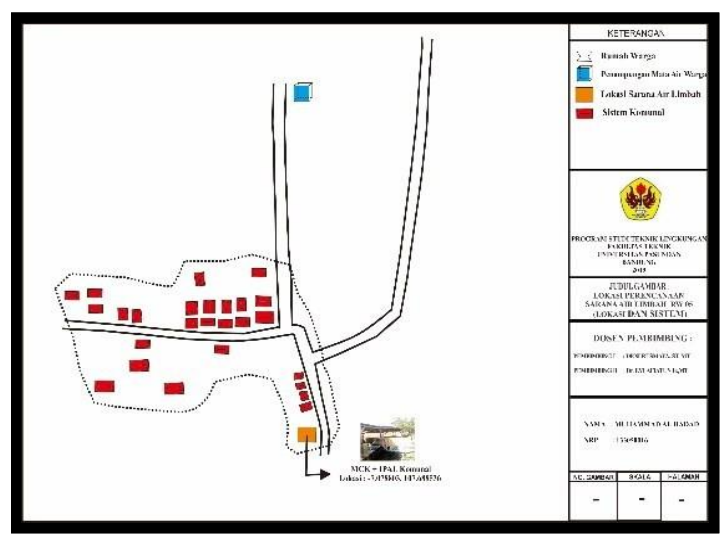

Figure 9 Planning Location of RW 05

Note : Location of WWTP

Number of households (HH): 150 (1 Kk 5 people) SSV01: $56 \mathrm{KK}$ (no problem), SSV02: 67KK (no problem) SSV 03: 27KK (with problem).

\section{d. Area of RW 100}

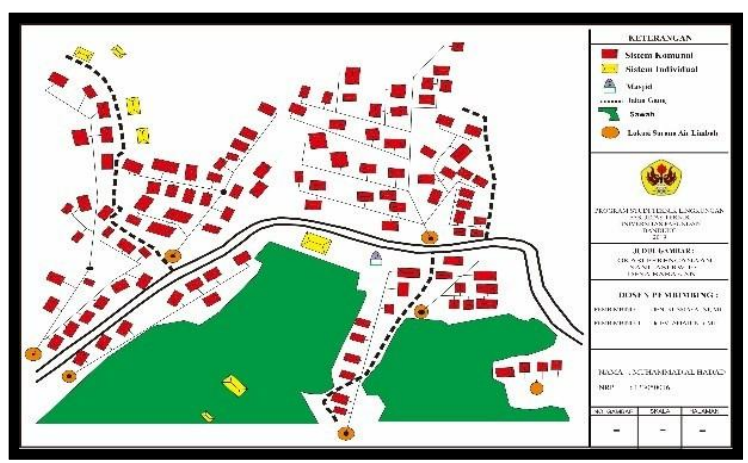

Figure 10 Planning Location of RW 10

Note: Location of WWTP

Number of HH: 89 (1 KK 5 people) SSV01: 19KK (with problem), SSV02: 34KK (with problem) SSV 03: 36KK (with problem)

\section{Selection of Wastewater Technology Options}

Things taken into consideration in selecting a domestic wastewater treatment system according to the Guidelines for Urban Wastewater Management of the Ministry of Kimpraswil in
2003 are based on factors of population density, existing water sources, and groundwater level depth, and the ability to finance (Hasbiah et al., 2019).

Based on these factors, processing system selections are made by comparing the advantages and disadvantages.

Selection of individual, communal or semicommunal systems is determined based on local conditions, population and socio-economic conditions. Communal and semi-communal systems can be applied to people who do not have private latrines and low economic levels (Rusmaya et.al, 2019).

Based on the results of the questionnaire analysis and the location survey of the suitable wastewater treatment system is the On-site system to be implemented in Babakan Village. The main consideration is the situation and conditions where technological capability and community financing are still low.

The considerations mentioned above, it is recommended to implement a communal system in the form of communal latrines + communal septic tanks and construction of public toilets + communal septic tanks.

The technology options chosen are Anaerobic Biofilter and stick tank. Anaerobic Biofilter has the advantages of removing high organic matter, relatively small land requirements, and low operating costs while the septic tank was chosen because it does not cause odors and flies, the required land area is not much, easy management, investment and operation costs are quite low., the resulting sludge is small, does not require electricity and materials are easy to obtain. This condition is very suitable for the condition of the community with a low economic level. 
The following is a plan for wastewater facilities and infrastructure.

Table 6. Domestic Wastewater Treatment Technology

\begin{tabular}{ccc}
\hline No & Location & Technology Option \\
\hline 1 & RW02/SSV 01 & Biofilter An-aerobik \\
\hline 2 & RW02/SSV 03 & Toilet, Communal Septic Tank \\
\hline 3 & RW 05/SSV01 & $\begin{array}{c}\text { Toilet, Communal Septic Tank, } \\
\text { Retention Area }\end{array}$ \\
\hline 4 & RW 10/SSV01 & Communal Septic Tank \\
\hline 5 & RW10/SSV02 & Communal Septic Tank \\
\hline 6 & RW10/SSV03 & Communal Septic Tank \\
\hline
\end{tabular}

\section{Conclusion}

Based on the description and explanation of the results of research in the Babakan village study area regarding domestic wastewater treatment facilities, it can be concluded as follows:

- The survey results conducted by Babakan Village show that access to wastewater facilities is still very minimal. This is shown because many people do not have private latrines and proper domestic waste treatment.

- Based on the weighting and scoring, the location in RW 02, RW 05 and RW 10 is the location for the planning study.

- Economic factors are the main burden for the community to build wastewater facilities, plus the lack of public awareness of environmental health. There are still many people who practice defecation and the use of cubkuk which has the potential to pollute the environment.

The technology options used for planning are anaerobic biofilter and communal septic tank. This condition is very suitable for the condition of the community with a low economic level.

\section{References}

Anonymous. (2018). Data Demografi penduduk Desa Babakan. Kantor desa babakan : Ciparay- Kab.Bandung

Ariola, M. M. (2006). Principles and Methods of Research (1st ed.). Rex Printing Company, Inc.: Queson, Philippines

Bartram, J, \& Cairncross, S. (2010). Hygene, Sanitation, and Water: Forgotten Fondations of Health. Plos Medicine, 7(11): e1000367.

Buku Putih Sanitasi 2016 : Area Beresiko Sanitasi

http://sippa.ciptakarya.pu.go.id/sippa_onli $\underline{\mathrm{n}}$ e/ws_file/dokumen_usulan/ssk/SSK_1807-2014.pdf

Hardjosuprapto, M. M. (2000). Penyaluran Air Buangan (PAB) (Vol. Volume II). Bandung: Institut Teknologi Bandung.

Hasbiah, A.W., Rusmaya, D., Apriani, D. (2019) Sanitasi Berbasis Masyarakat di Pesantren Putri Al-Ittihad, Kabupaten Cianjur. Journal of Community Based Environmental Engineering and Management, 3(1): 1-8.

Mulyatna, L., Wahyuni, S., Wilantri, R.S., Yustiani, Y.M. (2021) Evaluation on the sanitation facilities in the Gegerkalong Traditional Market, Bandung, Indonesia. IOP Conference Series: Earth and Environmental Science, 737(1): 012072

Prameswari, RA. \& Purnomo, A. (2014) Perencanaan Pelayanan Air Limbah Komunal di Desa Krasak Kecamatan Jatibarang Kota Indramayu. Jurnal Teknik POMITS, 3(2): 81-84

PerMen PUPR. (2017). Peraturan Menteri Pekerjaan Umum dan Perumahan Rakyat No. $\quad$ 04/PRT/2017 Tentang Penyelenggaraan Sistem Pengelolaan Air Limbah Domestik.

Rusmaya, D., Rochaeni, A., Dewi, N.P. (2019) Penentuan Fasilitas Sanitasi Berdasarkan Persepsi Santri di Tahfids Qur'an 
Madrasah Tsanawiyah (MTS) Assalaam, Kota Bandung. Journal of Community Based Environmental Engineering and Management, 3(1): 15-24.

Setiawati, R.T. (2017). Perencanaan Instalasi Pengolahan Air Limbah Domestik di
Kecamatan Simokerto. IPTEK Journal of Proceedings Series, 5.

Yustiani, Y.M., Rochaeni, A., Aulia, E. (2019). Konsep Pengelolaan Sampah di Desa Babakan Kabupaten Bandung. EnviroScienteae, 15(1): 121-126. 